\title{
Science Parks and the Attraction of Talents: Activities and Challenges
}

\author{
Eduardo Cadorin \\ HELIX Competence Centre, Linköping University, Department \\ of Management and Engineering, Linköping, Sweden, \\ eduardo.cadorin@liu.se \\ Magnus Klofsten \\ HELIX Competence Centre, Linköping University, Department \\ of Management and Engineering, Linköping, Sweden \\ magnus.klofsten@liu.se \\ Alberto Albahari \\ Universidad de Málaga - School of Industrial Engineering, Department \\ of Economics and Business Administration, Malaga, Spain \\ alberto.albahari@uma.es \\ Henry Etzkowitz \\ Science, Technology, and Society, Stanford University, Stanford, USA \\ henry.etzkowitz@triplehelix.net
}

\begin{abstract}
This paper explores activities undertaken by Science Parks to attract talent for their tenants. Despite the importance of accessing talent, there are very few studies focusing on this research area. The data in this investigation comes from seven cases studies on talent attraction activities carried out by three Science Parks in Sweden. We show that the parks conduct many different activities to attract talent including headhunting key personnel for start-ups, organising establishment platforms for foreign companies, and facilitating the exchange of knowledge and talent with higher education institutions. Science Parks house companies of different sizes, ages, and business orientations and therefore, park managers should be sensitive to the real needs of tenant firms when performing talent attraction activities.
\end{abstract}

(C) EDUARDO CADORIN ET AL., 2019 | DOI:10.1163/21971927-00601002

This is an open access article distributed under the terms of the prevailing CC-BY-NC License at the time of publication. 


\section{Keywords}

Science Park - talent attraction - Triple Helix - incubators - stakeholder - networking arenas

\section{Arabic}

$$
\text { تيالمحتلاو ةططشنا : ببهاوملا باطقتنساو تيملعلا تاعمبلا }
$$

Eduardo Cadorin, Magnus Klofsten, Alberto Albahari, Henry Etzkowitz

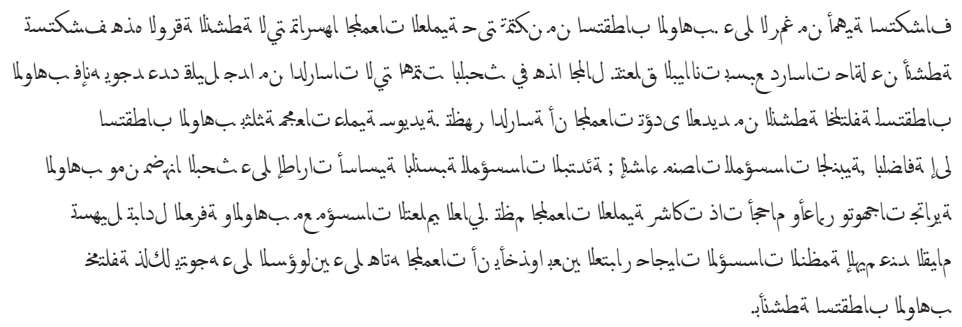

عيتافلا تاككلا

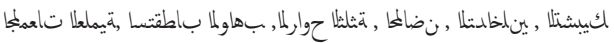




\section{Chinese}

\section{人才吸引和科学园：活动与挑战}

Eduardo Cadorin, Magnus Klofsten, Alberto Albahari, Henry Etzkowitz

\section{摘要}

本文探讨科学园为其租户吸引人才所开展的活动。尽管获得人才非常重 要, 但很少有研究矢注这一领域。我们的研究数据来自对瑞典三个科学园 区开展人才吸引活动的七个案例研究。研究表明：科学园开展了许多不同 活动以吸引人才, 其中包括为初创企业寻找矢键人员; 为外国公司组织建 立平台, 以及促进与高等教育机构的知识和人才交流。科学园区拥有不同 规模、年龄和商业定位的公司, 因此, 科学园管理者应该敏感地响应在租 公司开展人才吸引活动的实际需求。

关键词

科学园、人才吸引、三螺旋、孵化器、利益相矢者、网络竞技场

\section{French}

\section{Les parcs scientifiques et l'attraction des talents: activités et défis}

Cet article explore les activités entreprises par les parcs scientifiques afin d'attirer des talents. Malgré l'importance de la recherche des talents, très peu d'études y sont consacrées. Les données proviennent de sept études de cas sur des activités d'attraction de talents conduites par trois parcs scientifiques suédois. Nous démontrons que les parcs mènent des activités diverses et variées afin d'attirer les talents, dont la recherche de personnel clé pour les start-ups, l'organisation de plateformes d'établissement pour les entreprises étrangères, et la facilitation d'échanges du savoir et de talents avec les établissements d'enseignement supérieur. Les parcs scientifiques hébergent des entreprises de tailles, d'âges et d'orientations divers; par conséquent, les gestionnaires 
de parc doivent être attentifs aux besoins réels des entreprises locataires lorsqu'ils exercent des activités d'attraction de talents.

\title{
Mots-clés
}

parcs scientifiques, attraction des talents, Triple Hélice, incubateurs, actionnaires, arènes de réseautage

\section{Portuguese}

\section{Parques científicos e a atração de talentos: atividades e desafios}

\author{
Eduardo Cadorin, Magnus Klofsten, Alberto Albahari, Henry Etzkowitz
}

\section{Resumo}

O presente artigo explora atividades que parques científicos realizam a fim de atrair talentos para suas empresas inqulinas Apesar da importância de aceder talentos, há muito poucos estudos que enfoquem nesta área de pesquisa. Os dados são oriundos de sete casos de estudo de atividades de recrutamento de talentos realizadas por três parques científicos suecos. Mostramos que parques conduzem várias atividades diferentes com o intuito de atrair talentos, o que inclui recrutamento de profissionais-chave para startups, organização de plataformas de estabelecimento para empresas estrangeiras, bem como, facilitação e transferência de conhecimento e talentos com Instituições de Ensino Superior. Parques científicos abrigam companhias de diferentes tamanhos, tempo de atuação no mercado e orientação comercial e, portanto, gerentes de parques devem ser sensíveis às reais necessidades de suas empresas inquilinas ao realizar atividades de atração de talentos.

\section{Palavras-chave}

Parques científicos, atração de talentos, Hélice Tríplice, incubadoras, stakeholder, arenas de networking 


\title{
Russian
}

\section{Научные парки и привлечение талантов: инициативы и вызовы}

\author{
Эдуардо Кадорин, Магнус Клофстен, Альберто Альбахари, \\ Генри Иикович
}

\begin{abstract}
Аннотация
В настоящей статье рассматриваются инициативы, которые реализуются научными парками для привлечения персонала в компании. Несмотря на важность привлечения талантов, очень малое число исследований посвящено данной теме. В исследовании рассмотрены семь практических проектов по привлечению кадров, реализованных в трех шведских научных парках. Мы покажем, что парками проработано множество различных стратегий в сфере привлечение персонала, которые включают поиск кандидатов на ключевые позиции в стартапах; организация стратегических платформ для иностранных компаний; также стимулирование обмена знаниями и кадрами с Институтами высшего образования. Резиденты научных парков различаются размерами, возрастом и сферой деятельности, поэтому руководству парков следует внимательно относиться к потребностям компаний при реализации программ привлечения талантов.
\end{abstract}

\section{Ключевые слова}

Научный парк, привлечение талантов, Тройная спираль, инкубаторы, акционеры, сетевые взаимодействия 


\section{Spanish}

\section{Parques Cientificos y la attración de talentos : actividades y desafíos}

\section{Resumen}

En este artículo se exploran las actividades llevadas a cabo desde los parques científicos para atraer el talento para sus empresas residentes. A pesar de la importancia de acceder al talento, hay muy pocos estudios que se centren en este área de investigación. Los datos vienen de siete casos de estudio sobre actividades de atracción de talento llevadas a cabo en tres parques científicos suecos. Se demuestra que los parques articulan distintas actividades para captar talento, entre las que se incluyen identificar y reclutar personas clave para las "start-ups", organizar plataformas de aterrizaje para o establecimiento para empresas extranjeras, así como facilitar el intercambio de conocimientos y talento con instituciones de educación superior. Los parques científicos acogen empresas de diversos tamaños, edades y orientación empresarial por lo que las entidades de gestión de los parques deberían considerar responder a las necesidades reales de sus residedentes en los que concierne a las actividades de atracción de talento

\section{Palabras clave}

Parques Científicos y Tecnológicos, atracción de talento, Triple Hélice, incubadoras, grupos de interés, networking arenas

\section{$1 \quad$ Introduction}

Science Parks are policy-driven agglomerations whose management function is to actively engage in supporting the formation and growth of on-site technology and knowledge-based firms (Huang et al. 2012; Albahari et al. 2018a). There are different ways of describing Science Parks, although the definition by the International Association of Science Parks and Areas of Innovation (IASP), which is the one we consider for this study, is frequently used (Colombo and Delmastro 2002; Fukugawa 2006): 
"Science Park is an organisation managed by specialised professionals, whose main aim is to increase the wealth of its community by promoting the culture of innovation and the competitiveness of its associated businesses and knowledge-based institutions" (IASP 2017).

Over the years, Science Parks have been transformed from a single-purpose organizational model based on land tenancy ${ }^{1}$ into an interactive, multifaceted organizational model with a more complex set of roles and relationships (Etzkowitz and Zhou 2018). To meet their objectives, Science Parks provide valueadded services such as office space and facilities, but also supports the flow of knowledge and talent between universities and park companies (Bellavista and Sanz 2009). Studies highlight that one of the most valuable service that Science Parks provide for tenants are the links to universities and access to various academic talent (Colombo and Delmastro 2002; Fukugawa 2006). Moreover, Albahari et al. (2018b) show that the supply of soft value-added resources (process-oriented) is highly related to access to key experts, mentors, and entrepreneurs who are crucial for the growth and development of firms. To successfully connect with such individuals, companies have transformed their human resource management processes into a new strategic level called talent management, which aims to "attract, develop, motivate and retain talent" (Thunnissen et al. 2013, p. 1752). Indeed, a factor differentiating companies and marking one as more competitive than another lies mainly in the human capital resources (Holland et al. 2007).

Talent is considered a crucial human resource for the development and growth of companies (Barney 1991; Holland et al. 2007). Nevertheless, there is no consensus on how talent should be defined, and the meaning of talent within the human resource context is often taken for granted (Gallardo-Gallardo et al. 2013; Mcdonnell et al. 2017). Perhaps the challenge to find a precise definition of talent is because it is a subjective concept with many potential interpretations and meanings for those who are using it and the context they are operating in when studying the phenomenon (Tansley 2011; Florida 2012). For purposes of this paper, we concur with the following definition since it places the individual front and centre as talent and key actor in the development and performance of organisations,

"Talent consists of those individuals who can make a difference to organisational performance, either through their immediate contribution or in the

1 Called by some authors as 'firm hotels' (Löfsten and Lindelöf 2002, p. 864) in a pejorative sense. 
longer-term by demonstrating the highest levels of potential" (Chartered Institute of Personnel and Development 2007, p. 3)

Thus, talents are those who because of their skills, knowledge, creativity, professional competence, communication and leadership ability (Saddozai et al. 2017), are capable to add value to a company and take it to a higher level of performance - 'high performers', or even having the potential to become such agents of business transformation - 'high potentials' (Thunnissen et al. 2013; Mcdonnell et al. 2017). Salvat and Marcet use three knowledge-related categories to classify talent: i) theoretical knowledge; ii) know-how; and iii) discernment; and two talented-worker-factors for further differentiation: iv) readiness to act and v) engagement (Salvat and Marcet 2008).

While there is extensive literature on Science Parks, and the significance of attracting talent is well known, there is limited knowledge on the talent attraction activities that occur within existing parks (Koh et al. 2005). Moreover, we have little knowledge about how Science Parks organise and collaborate their talent attraction activities despite the importance of the subject.

This paper explores the following two research questions: $i$ ) what are the activities that Science Parks undertake in order to attract talent for their tenant companies? ii) What are the main challenges that the parks experience in this regard? Filling this knowledge gap will shed light on the mechanisms used by Science Parks to create value for tenant companies and it will highlight a number of policy implications related to talent attraction activities.

Following a presentation of the literature in Section 2, the third section describes the methodology adopted and the process of data collection for this study. Section 4 introduces the Science Parks under investigation and the talent case-studies involved, while Section 5 analyses and discusses networking, and the supportive and integrative activities used in talent attraction in the parks. Section 6 examines the results, provides conclusions based on the evidence, and notes the paper's contributions. The final part proposes policy implications and future research.

\section{Literature Review}

The debate on Science Park's effectiveness as a development and innovation policy tool is still open. Yet many empirical studies have demonstrated that being located in a Science Park may have a positive effect on tenants' performance. Positive impacts have been found in terms of sales growth (Löfsten and Lindelöf 2002, 2003), employment growth (Colombo and Delmastro 2002; 
Löfsten and Lindelöf 2002, 2003) innovation output (Siegel et al. 2003; Squicciarini 2008, 2009; Huang et al. 2012; Vásquez-Urriago et al. 2014), and R\&D productivity (Siegel et al. 2003; Yang et al. 2009).

A recent theme in the literature on Science Parks takes into consideration parks' heterogeneity, recognising that some parks work better than others in generating value for tenants (Albahari et al. 2017, 2018a). In line with this, some authors have attempted to understand how Science Parks create value for tenants, something which is still unclear (Albahari et al. 2018b). A common view is that an essential feature of every successful Science Park is the provision of services by parks' management and in particular, it is thought that fostering creation and development in young firms through services related to financial and marketing issues, is of key importance (Storey and Tether 1998; Westhead and Batstone 1998; Löfsten and Lindelöf 2003).

In pursuit of development and growth, companies have developed a new strategic level in human resource management called talent management focusing on a selected group of people rather than on workers in general (Saddozai et al. 2017). Managing talent should not be the ultimate goal, but rather it is a by-product as managerial activities that develop employees or try to achieve specific levels of turnover. The core of talent management is to anticipate the demand for a particular human resource and then establish a plan to satisfy it (Cappelli 2008). Talent management is "an integrated set of processes, programs, and cultural norms in an organization designed and implemented to attract, develop, deploy, and retain talent to achieve strategic objectives and meet future business needs" (Silzer and Dowell 2010, p. 18). Theoretically, talent management services may be a relevant component offered by Science Parks and designed to make an essential contribution to tenant's talent management practices.

Proper talent management is a critical determinant of organisational success (Ashton and Morton 2005; Nijs et al. 2014). It can be a mechanism through which knowledge resources can be exploited to enhance firm performance (Chadee and Raman 2012). Firms seeking to improve their talent management practices could benefit, in particular, from adopting a collaborative network approach, which can readily emerge within a Science Park setting (Hu 2008; Schweer et al. 2012). Both newer and more established tenant firms could benefit from talent management actions promoted by the Science Park management. Younger firms, as start-ups, are often more reliant on the park's support when it comes to recruiting talent (Phan et al. 2005). Compact start-up teams sometimes lack members with specific expertise, e.g. managers and CEOs (Bøllingtoft and Ulhøi 2005). Therefore, the Science Park may support them in their search for professionals who have the required knowledge and background, 
and who come with a profile compatible with other members of the team (Phan et al. 2005; Albahari et al. 2018b). In contrast, mature companies tend to have more consolidated human resource management processes and therefore are more often able to engage independently in talent attraction activities (Cappelli 2008). Still, since older companies "require a broader array of talents" (Siegel et al. 1993, p. 170), the Science Park and its likely proximity to a university with a continual flow of graduates, can become the primary provider of talent and contribute to the talent attraction processes of these older companies (Florida 1999; Gibb and Hannon 2006; Etzkowitz 2008).

According to Engel et al. (2018), firms of all maturity levels as well as entrepreneurs, want to reside close to other firms, universities, and research centres. Some studies have demonstrated that Science Parks encourage the formation of links between local universities and tenants, which often results in the recruitment of university graduates (Felsenstein 1994; Westhead and Storey 1995; Vedovello 1997; Colombo and Delmastro 2002; Fukugawa 2006). Even so, the flow of talent from universities to parks' tenants is not necessarily a spontaneous process (Cadorin et al. 2017). It is up to the parks to provide an environment with career and individual development opportunities that can positively contribute to companies in their talent attraction processes. In fact, talents are mobile people, who seek out places where they feel encouraged to grow professionally and where they will have an opportunity to work together with other talents (Florida 1999). Additionally, the brand and the prestigious address of the park also contribute to creating a favourable scenario for attracting talent (Storey and Westhead 1994).

The topic of proper talent management and the potential impact of Science Parks on tenants' talent management practices, has received scant attention in the literature. Koh et al. (2005) found in their study of Singaporean Science Parks that the presence of talent attraction activities is a crucial ingredient behind the success of the parks. Cadorin et al. (2017) demonstrated how Science Parks undertake a number of different talent attraction activities from strategic recruitment within start-ups to providing arenas where people meet to exchange knowledge and networks.

To summarise, Science Parks are organisations that provide infrastructure and services to support the development of their tenant companies (Colombo and Delmastro 2002). Among the services offered by Science Parks, activities to attract talent and to support tenants in their talent management activities is something new in the field of park management (Cadorin et al. 2017). Talentrelated activities performed by parks are in line with those who advocate a more hands-on role for parks' management (Westhead and Batstone 1998; Löfsten and Lindelöf 2002). 
Our study comprises seven different talent-attraction cases (Table 1) that have emerged within three Science Parks in Sweden: Ideon Science Park (ISP), Lindholmen Science Park (LSP) and Science Park Mjärdevi (SPM) (Table 2).

We begin with SPM, an internationally renowned park. Having been operating for over 30 years, there is a large amount of available data accessible to the researcher including stories of success and failure in talent attraction. Both ISP and LSP came to our attention during interviews with representatives of SPM, which led us to conduct an in-depth study of their websites to identify activities potentially related to talent attraction. The choice of these three Science Parks situated in one country made it possible to illustrate a broad spectrum of talent attraction activities in Science Parks with similar characteristics.

We built on the method of case study analysis in line with Eisenhardt and Graebner who have written (2007, p. 25): "A major reason for the popularity and relevance of theory building from case studies is that it is one of the best (if not the best) of the bridges from rich qualitative evidence to mainstream deductive research." The case study method allowed us to understand the processes behind the emergence of talent attraction activities in Science Parks. We could study the key people involved, the context in what the activity is operating in and the observed outcomes of each activity (Yin 2003; Gioia et al. 2013).

We generated the table for conducting interviews by means of a progressive refinement process until we obtained the final version. We listed the main information needed from each park, noting that they all shared similar characteristics, such as age of park, orientation and - being located in the same country - same legislation and same culture. Once defined, the table was considered complete and was used in all interviews.

Before performing the interviews, we set up a panel of key individuals, such as former and current parks CEO's, incubator managers, and project leaders of talent activities that over time have been in the management and implementation of the Science Parks' administrations (see Appendix). The rationale behind the interviews was to get leads on potential cases, acquire historical data, verify the content validity, and receive feedback on the design and development of our study (Florin et al. 2007). As this study aimed to obtain the Science Park's perspective, we did not interview any member of the tenant companies.

Data collection for the study was done through semi-structured interviews with panel members as well as with new individuals suggested by our respondents, for example, managers of incubators and event managers in parks. Complementary secondary sources were used as well, including research papers on 
the studied parks (Park 2002; Hommen et al. 2006; Kruse 2015; Albahari et al. $2018 \mathrm{~b}$ ). We also used various internal documents and reports provided to us, and the internet websites of the three Science Parks. We were able to note activities similar to Mjärdevi (SPM) in the other two parks, but the aim of this study was not to compare similar activities in different parks. It was to look at different talent activities performed in similar Science Parks.

The first interviews began in 2015, with most occurring in 2016. Together, the 13 personal interviews comprise around 25 hours. Additionally, 3 complementary telephone interviews were held with certain respondents, each lasting between 15-30 minutes. The initial interviews were held with the founding director of SPM, who had been CEO until 2013, which is to say, for the first 30 years of the park. This respondent was crucial to the success of the research project. We established a research relationship with the subject similar to the interactive research approach of Ellström et al., which fosters a two-way flow of information and knowledge between research and practice (Ellström et al. 2011).

The studied Science Parks undertake many different activities to attract talent (Table 1). For example, Soft Landing focuses on attracting foreign companies while LEAD, seeks to recruit professionals to start-up tenants. For both businesses and incoming professionals, SPM Office and CEVT HR, offer services designed to support tenant development. Shadow Board and Tech Pilots promote integration between young talent and park stakeholders, and Ideon Meeting offers park tenants a physical space for expanding their network of talent contacts. The parks face a number of challenges when it comes to defining roles and developing models for collaboration with key stakeholders such as universities and municipalities. There is an overall perceived challenge of getting regional actors involved in talent attraction and it is thought that doing so will make for a potentially more efficient process. And there are some specific positive outcomes associated with Tech Pilots that have allowed firms to strengthen their competitiveness, develop new business networks, and learn how to be more attractive to young professionals.

\subsection{Networking Activities}

All three Science Parks perform activities that develop and strengthen their image with the aim of attracting talent. The mission is to get attention from a talented workforce on the regional, national and international markets. Ideon 


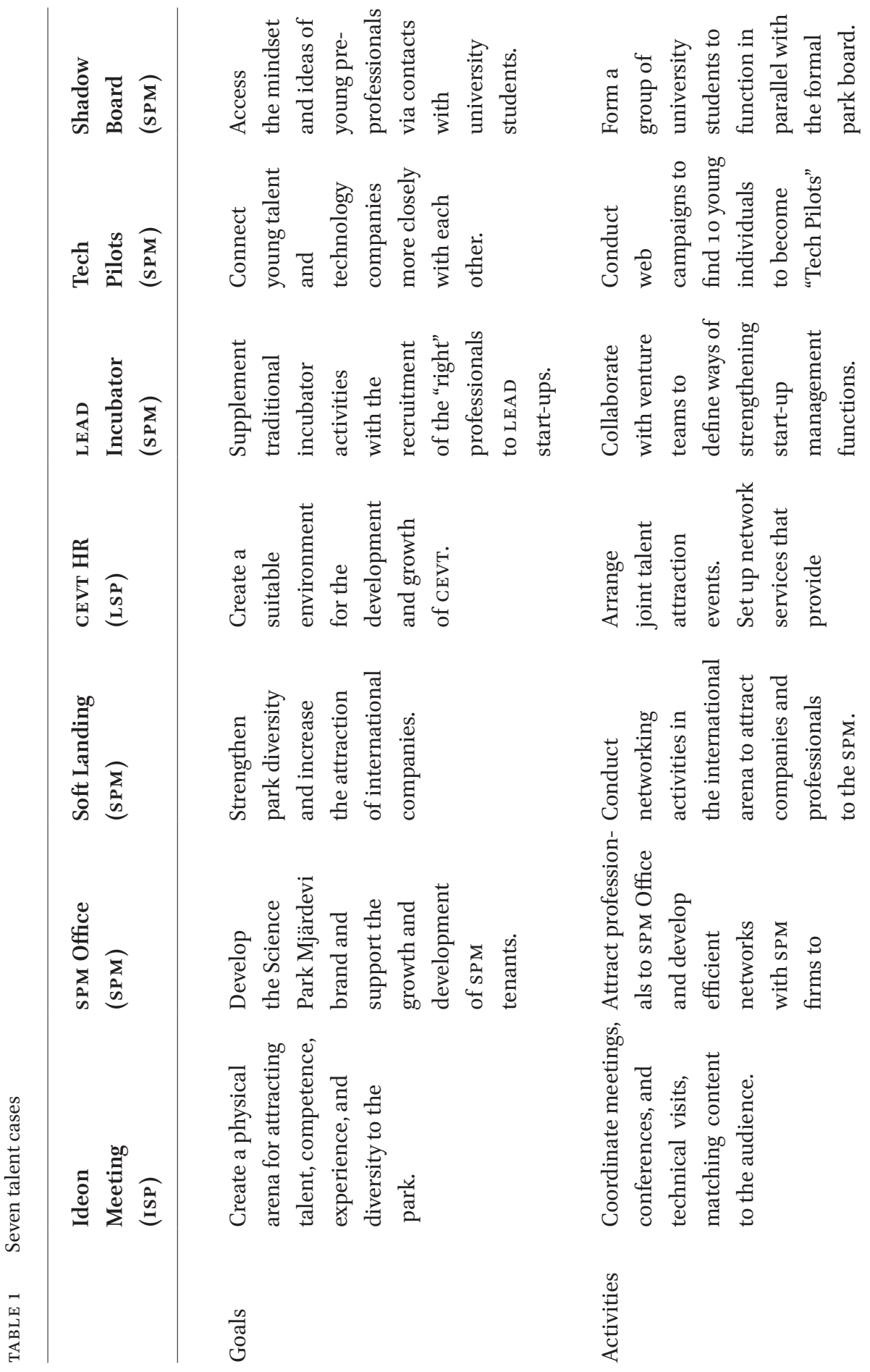




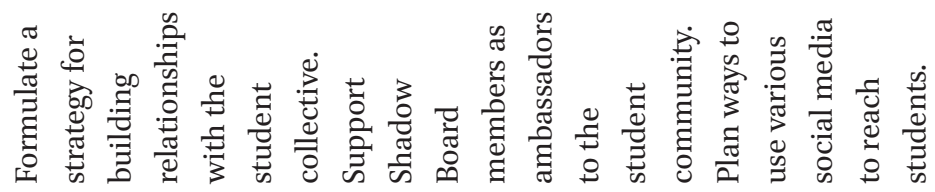

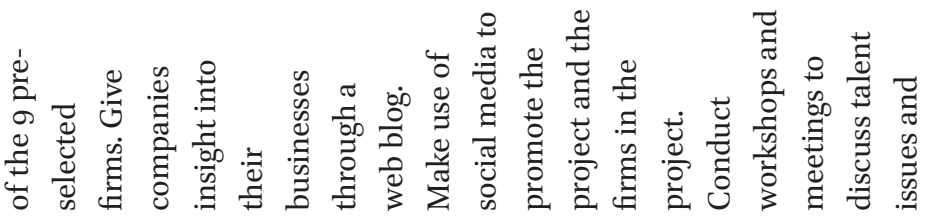

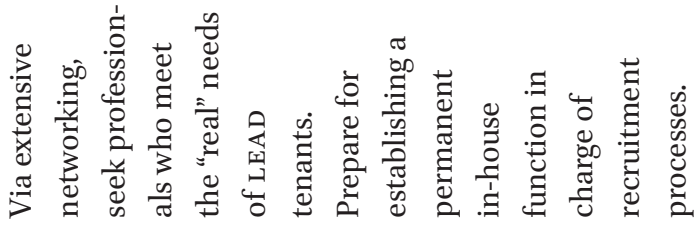

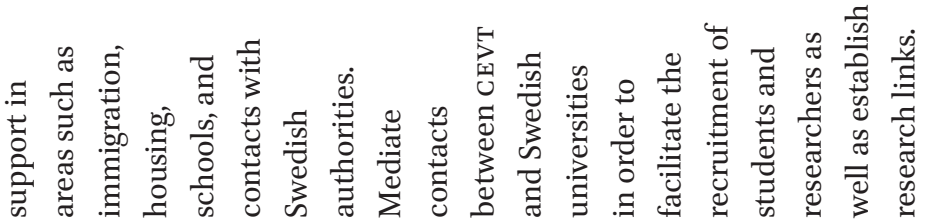

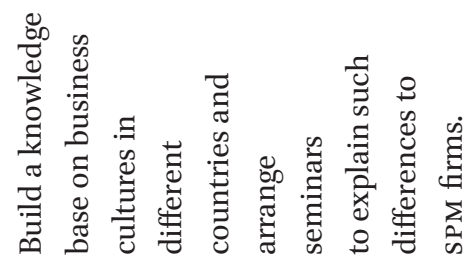

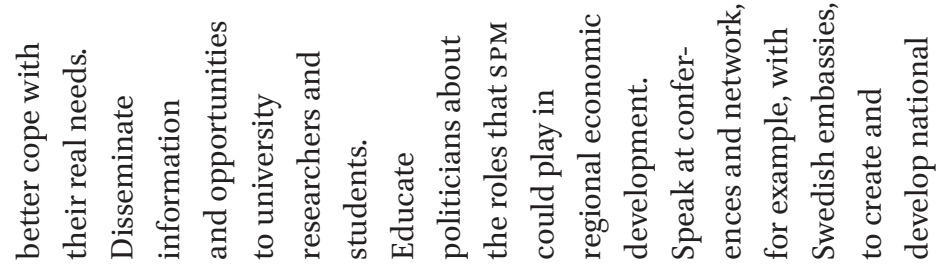

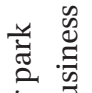

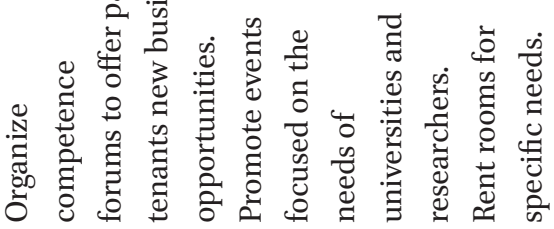




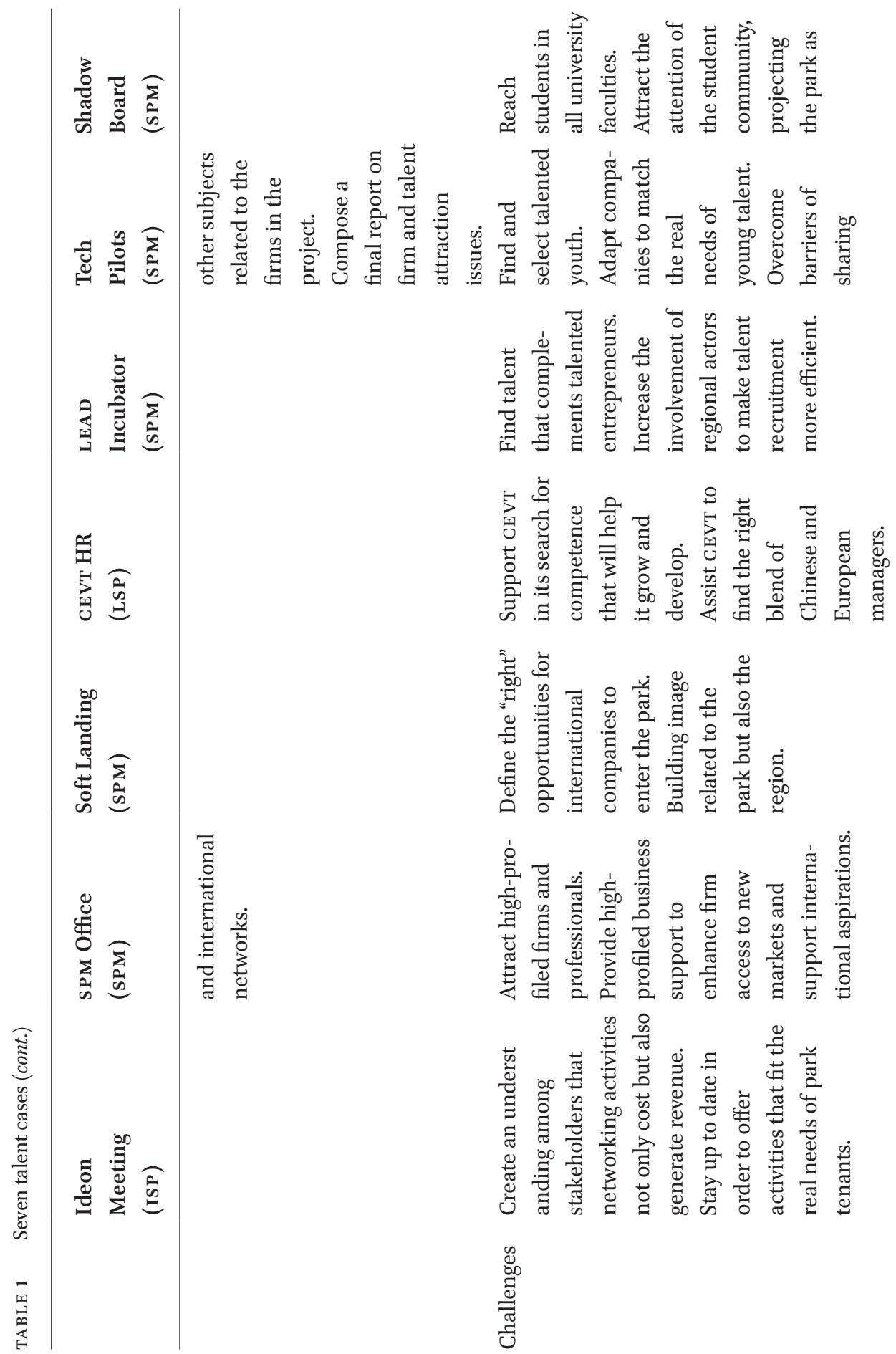




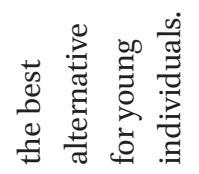

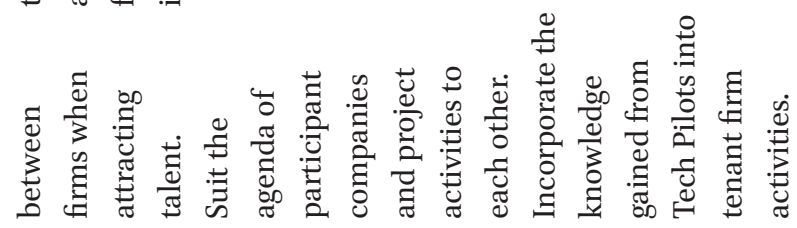
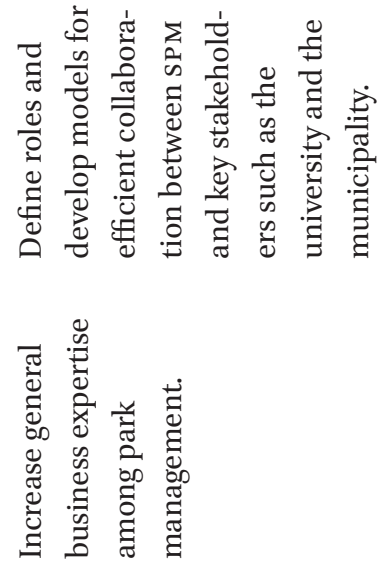


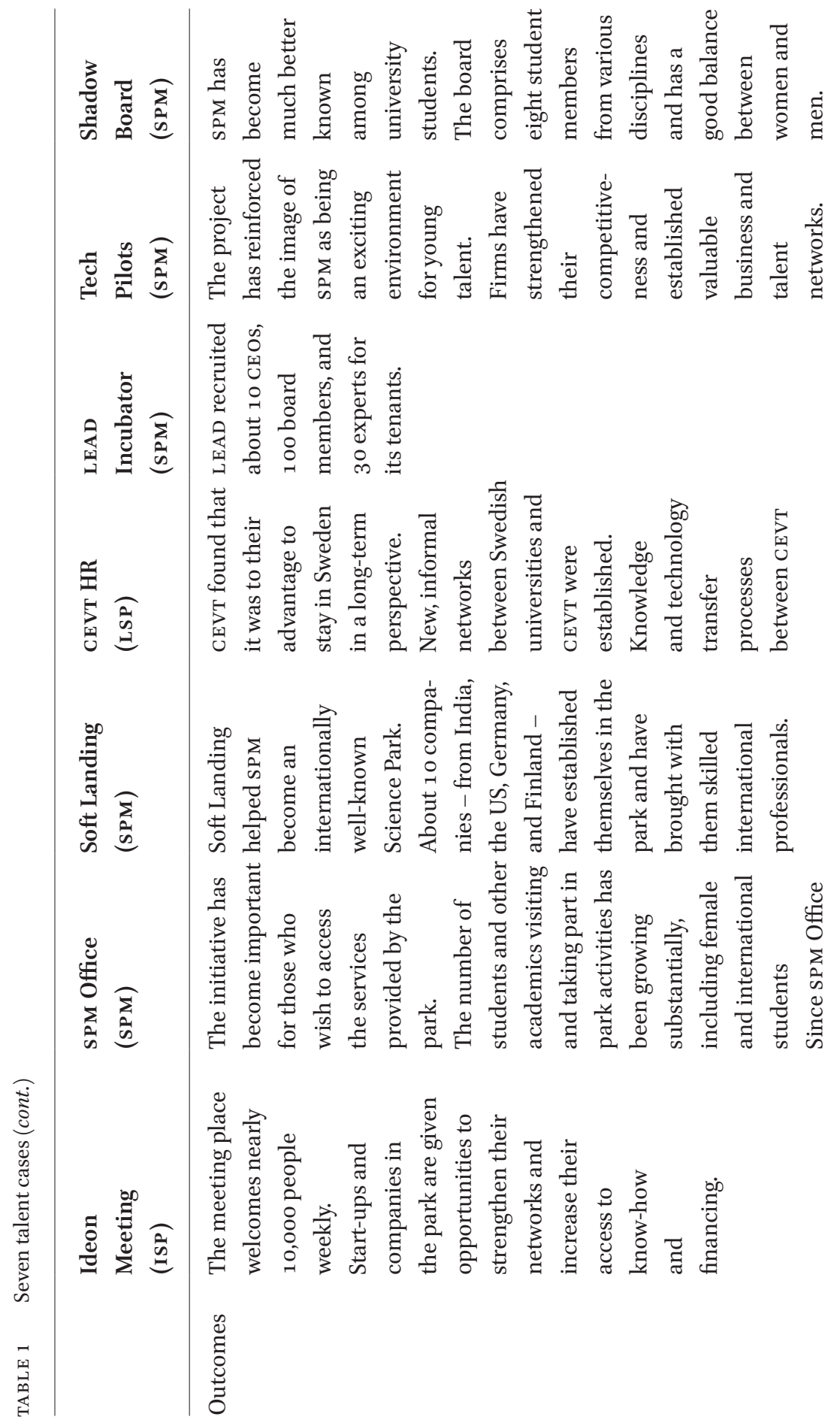




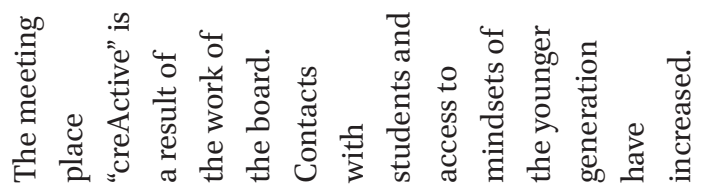
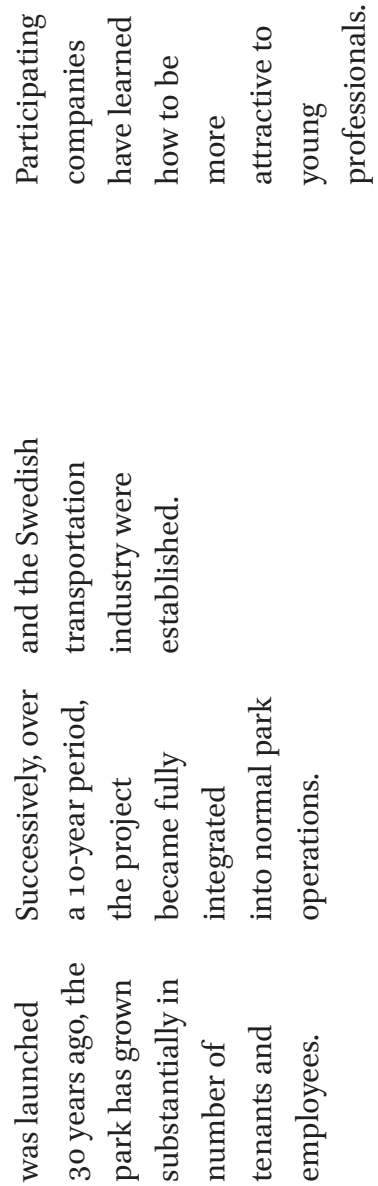
TABLE 2 Three Swedish Science Parks

\begin{tabular}{|c|c|c|c|}
\hline Characteristics & $\begin{array}{l}\text { Ideon Science } \\
\text { Park (ISP) }\end{array}$ & $\begin{array}{l}\text { Lindholmen } \\
\text { Science Park (LSP) }\end{array}$ & $\begin{array}{l}\text { Science Park } \\
\text { Mjärdevi } \\
(\text { SPM) }\end{array}$ \\
\hline Foundation year & 1983 & 2000 & 1984 \\
\hline Localization & $\begin{array}{l}\text { In Lund, in } \\
\text { proximity to the } \\
\text { Lund University. }\end{array}$ & $\begin{array}{l}\text { In Gothenburg, } \\
\text { closely located to } \\
\text { the Chalmers } \\
\text { University of } \\
\text { Technology and } \\
\text { University of } \\
\text { Gothenburg. }\end{array}$ & $\begin{array}{l}\text { In Linköping } \\
\text { sited near } \\
\text { Linköping } \\
\text { University. }\end{array}$ \\
\hline $\begin{array}{l}\text { Main } \\
\text { competences }\end{array}$ & $\begin{array}{l}\text { ICT, connectivity, } \\
\text { Life science, } \\
\text { cleantech, } \\
\text { medtech, smart } \\
\text { material and food } \\
\text { innovation. }\end{array}$ & $\begin{array}{l}\text { Transport, ICT, and } \\
\text { media industries. }\end{array}$ & $\begin{array}{l}\text { ICT, visualisa- } \\
\text { tion, simula- } \\
\text { tion, medical } \\
\text { technology, } \\
\text { mobile } \\
\text { broadband, } \\
\text { vehicle safety } \\
\text { and security } \\
\text { systems }\end{array}$ \\
\hline Figures (2018) & $\begin{array}{l}\text { 40o firms and } \\
\text { 9,ooo employees. }\end{array}$ & $\begin{array}{l}350 \text { firms and } \\
11, \text { ooo employees. }\end{array}$ & $\begin{array}{l}370 \text { firms and } \\
7,000 \\
\text { employees. }\end{array}$ \\
\hline
\end{tabular}

Meeting, for example, organises events (see quote below) such as technical visits, conferences, workshops, business meetings, and skills forums.

Often the visiting groups are a small group of people with a clear purpose of their visit. That could be to collect information, meet the people or start-ups, get inspiration from the environment or the region. We often take them on site visits out of the house. We need to meet their needs by connecting them with the right people, decision-makers and politicians in the region. We only 
propose the program, but we never set the agenda. (Ideon Meeting Operations Manager)

The park management claims, however, that it is crucial to creating an understanding among stakeholders, that networking activities not only cost but also generate revenue, which in itself is a challenge.

To disseminate information about the park to potential talent recruits, SPM Office sends speakers to international conferences and applies for assistance from the embassies of target countries. The internet and social media also proved to be effective tools for connecting with foreign talent. As a result, park areas designed for meetings and events, such as creActive and Ideon Meeting, have, over the years, received an increasing number of visitors and have enabled park companies and start-ups to expand their networks and find new business opportunities and know-how. In this, they stress the importance of networking outside the Science Park, but also within the park context. A former CEO of SPM described the vital role that creActive plays in integrating students into the park,

SPM attracted more female and international students (even didn't focus on internationals) than earlier. Moreover, SPM also had an increasing number of students visiting and "using" creActive and by doing that they also realized what SPM is all about. (Former CEO of SPM)

\subsection{Supportive Activities}

Supportive activities, which aim to provide favourable conditions to attract talent, can occur at very early phases of the park's development, as the activities developed by SPM Office to recruit professionals to create an in-house support staff that offers find-and-recruit services, especially with an eye to increasing the internationalisation of park companies.

Our interviews show that support services are required when welcoming international companies and talent to help minimise barriers that may arise when businesses and individuals settle in the park. Such services make the park more attractive. Furthermore, the cases show that the studied parks frequently interact with the political system in order to bridge the obstacles encountered when international talent and companies come into the Park. They provided services to help integrate newcomers into Swedish system such as housing, immigration assistance, and other governmental formalities. Such activities were found in the Soft-landing and CEVT cases where they worked to integrate companies and professionals within the park so as to lay the groundwork for long-term relationships and collaborations between international 
talent and stakeholders - believed to be crucial for the future growth and development of the Science Parks.

The manager of the LEAD incubator pointed out that they use various business networks to find leaders and other strategic personnel for its tenants:

Our task is to support the development of the companies we work with, and to me, that also includes attracting and recruiting talents. LEAD has a vast network of contacts ranging from both formal and informal connections, and both private and public organisations. (CEO of LEAD)

The incubator plans to establish a permanent function to manage the process of talent attraction. It will include setting-up external collaborations to more efficiently reach talented individuals headed to work with the incubator tenants within the Science Park.

Another talent attraction case is the Tech Pilots project that brings young talents to selected park tenants in order to develop new business solutions, and also teach firms how to become more attractive to young talent. Through interactive workshops and a project blog, an exchange of knowledge and experience, not only between young talents and firms but also between the participating firms, became possible. An additional outcome of this interaction was that talented individuals who participated in the project became ambassadors for the Science Parks. This in turn, led to strengthening the image of the parks and the establishment of valuable business and talent networks. The final project report expressed satisfaction with these efforts:

Some of the tech pilots knew about some of the companies before joining the program, butfor many of them it became a "wow"-experience, realizing that there was so much cool technology in Mjärdevi and Linköping. Some of them stressed that Linköping is really good in system technology, combining different technologies and integrating them. For many of the pilots, this was their first contact with Linköping, and the first impression was very good. (Mjärdevi 2016, p. 2)

\subsection{Integration Activities}

The interviews showed that university students, despite their proximity, do not easily become engaged in Science Park activities. As a result, the parks established initiatives to reach students. For example, a group of students was selected to work on the Shadow Board alongside the regular board members involved in the strategic development of the park. Through a Shadow Board, the park can access the aspiration, mindset and innovative ideas of a new 
generation of potential entrepreneurs and business leaders. The Science Park management indicated that through the Shadow Board they succeeded in attracting students from various disciplines and became better known in the university community. The ideas exchanged enabled the park to implement a portfolio of activities, such as "creActive", which became a popular meeting place for entrepreneurs and students. The student board members become park ambassadors to other students allowing for a dyadic flow of information between the student community and the park management. One of the park's CEO pointed out:

The dual flow of information between students and the SPM management is the most important contribution of the Shadow Board for SPM (Former CEO of $S P M)$.

Attracting talent and matching the recruited individuals with the real needs of the tenant firms is a perceived challenge for the parks. As well, management faces the problem of gaining the students' attention and reaching the student community with their message. The CEVT case showed one way of reaching potential talents at a university. Here the Science Park mediates between tenants and Swedish universities in order to attract both students and researchers to the park as well as to establish technology transfer links. The mediation carried out by the park was a deciding factor for CEVT's long-term business engagement in Sweden.

Working to fill the gap in research on Science Parks, this study looked at methods for attracting talent for tenant firms and investigated the importance of such activities. In the cases analysed, we considered their objectives, activities, problems and results, independent of any specific park. We point to a number of challenges the parks face when organising collaborative networks to attract talent and meet the real needs of tenant firms concerning human resources.

Our study generated new insights into the portfolio of services provided by parks in order to develop talent attraction activities and attain Science Park success, such as the promotion of ties between university students and park tenants and the creation of an attractive environment for companies and talented individuals. Earlier research on mechanisms to stimulate the growth and development of entrepreneurs and their firms (including in Science Parks) stresses the importance of having a balance of "configuration" and "process" 
oriented resources in the supply of business support (Autio and Klofsten 1998; Albahari et al. 2018b). Many studies have shown that such process-oriented resources include many different activities related to business advice (Löfsten and Lindelöf 2002; Ferguson and Olofsson 2004), financing (Klofsten et al. 1999; Colombo and Delmastro 2002), and networking (Deeds et al. 2000; Phan et al. 2005; Leon 2008). The current study adds talent-attraction as a new theoretical element (c.f. Bellavista and Sanz 2009, p. 502) indispensable to understand the influence of human resources on the Science Parks development as well as the services they provided in order to promote the growth and development of their tenant firms.

On the activity level, our evidence shows that talent attraction in Science Parks can be implemented in many ways including $(i)$ finding key personnel and management professionals for young and growing firms, (ii) creating platforms for attracting international firms and professionals, (iii) facilitating the exchange of knowledge and talent with higher education institutions, and $(i v)$ conducting networking activities with student collectives. Often, the actors, such as the park management team, incubators, universities and tenant firms collaborate in an attempt to create a positive image of the park (Ferguson and Olofsson 2004). This positive image in turn, reaches talented individuals and facilitates joint projects connected to the park (Cadorin et al. 2017). Finally, we are aware of the large amount of research on human resources including on human and social capital, for example, the entrepreneurship research by Davidsson and Honig (2003) and by De Cleyn et al. (2015). Our study, however, does not aim to understand how the talent development process occurs. Rather, our aim is to contribute to the literature on Science Parks by concretely presenting and analysing the activities undertaken to attract talent to tenant firms.

\section{Policy Implications and Future Research}

Empirical studies on Science Parks have shown that they have a positive impact on tenants' performance (Siegel et al. 2003; Squicciarini 2008, 2009; Huang et al. 2012; Vásquez-Urriago et al. 2014). Nevertheless, authors seldom hypothesize about the mechanisms parks use to create value that results in higher performance for tenants. In this sense, our research has identified one of these mechanisms. If it is true that good talent management practices improve firms' performance, and parks perform effective talent-related activities, then we can conclude that such park activities are tools through which Science Parks can improve tenant performance. We should not forget that the recipients of 
talent-management practices performed by parks are tenants, i.e., the parks' source of income. Our findings provide justification for substantial public investments in Science Parks (Albahari et al. 2013).

Several of the activities we describe focus on supporting firms of different sizes and degrees of maturity. More than one study has observed the importance of designing support activities based on such criteria and we believe this to be imperative for Science Parks (Chordà 1996; Storey and Tether 1998). Talent attraction must address real ways to support tenant firms. In the case of start-ups, for example, it is essential to consider ways of protecting new firms from the "liability of newness" i.e, the high risk of failure in the first years of existence (Bergek and Norrman 2015). Because start-ups lack reputation and stable business relationships, they need time to gain market legitimacy. Therefore, in this scenario, Science Park talent management teams should understand the nature of start-ups and help recruit talent consistent with the needs of the new firm.

Science Parks form a critical mass that can be influential when talent in another region is deciding whether a move to a new region is to their benefit (Laur 2015). The attracting park must be able to offer exciting and challenging work, something more probable once it has reached a critical mass. This condition is essential if talent is to be attracted from world metropolises to smaller cities. Areas of competence, size of city, and scale of the park all affect critical mass.

Branding is another critical factor. Talent tends to look for reliable brands in their areas of knowledge and lifestyle (Papademetriou et al. 2008; Thunnissen et al. 2013; Chartered Institute of Personnel and Development 2017). These assets are particularly valuable when it comes to attracting "young, mobile, highly skilled and talented business groups." (Cannon 2008, p. 38). Therefore, the city, park, and tenant brands attract talent that has brand-related expertise. Thus, critical mass and the right brand are vital to the survival and growth of the park.

The shelf life of knowledge is limited. Ways of confirming and updating what is "known" are survival tools. One such tool is to attract university students and other representatives of tomorrow's talent (De Miranda et al. 2009). Students tend to be reasonably mobile, anxious to travel the world, and enthusiastic to seek challenges in employment (Bienkowska and Klofsten 2012; Frederiksen et al. 2016). Finding ways to network with student collectives should place near the top of any Science Park's priority list. Park tenants and talent attractors - with the world as their market - should use every opportunity to expand their networks internationally, to make new contacts, and 
to explore new entryways. The goal is internationalisation, which is now a requirement for those who want not only to survive, but to grow and drive Science Parks forward by attracting the best talent from a global pool.

The present study relies on seven cases at three Science Parks, and each case differs in focus. It is highly likely that more forms of talent attraction activities can be found at Science Parks. Future studies, with either a qualitative or quantitative approach, can target talent attraction activities by doing, for example, a comparative analysis of Science Park characteristics, structure, stakeholders and types of talent involved. There is the obvious future research question related to understanding the motivations and methods that Science Parks use to collaborate with stakeholders on talent issues. The challenge is to identify with greater precision the types of activities Science Parks undertake to attract talent. This study lays out a number of roads of inquiry on the future of Science Parks.

\author{
Abbreviations \\ CEO - chief executive officer \\ CEVT - China Euro Vehicle Technology AB \\ IASP - International Association of Science Parks and Areas of Innovation \\ ICT - Information and communication technology \\ ISP - Ideon Science Park \\ LEAD - LiU Entrepreneurship And Development \\ LiU - Linköping University \\ LSP - Lindholmen Science Park \\ R\&D - Research and Development \\ SPM - Science Park Mjärdevi
}

\title{
Declarations
}

\section{Availability of data and material}

The datasets obtained and analysed during the current study are available from the corresponding author on reasonable request.

\section{Competing interests}

The authors declared no potential conflicts of interest concerning the research, authorship, and publication of this article 


\section{Authors' contributions}

EC and MK conceptualised the study, collected and analysed the data. EC, MK and HE wrote the first draft of the manuscript. AA contributed to the literature review and policy implications. AA and HE revised the manuscript and advanced the practical and theoretical contributions of the article. All authors read and approved the final manuscript.

\section{Funding}

This work is supported by CNPq (National Council for Scientific and Technological Development) - Brazil, and The Helix Competence Centre at Linköping University.

\section{Acknowledgements}

The authors are most grateful to all respondents who supported this research project with valuable information and validation of data. We are also very thankful to our research colleagues at the Department of Management and Engineering of Linköping University for contributing valuable comments on several versions of the manuscript.

\section{References}

Albahari, A, Barge-Gil, A, Pérez-Canto, S, Modrego, A (2018a). The influence of Science and Technology Park characteristics on firms' innovation results. Papers in Regional Science 97:253-279. doi: 10.1111/pirs.12253.

Albahari, A, Catalano, G, Landoni, P (2013) Evaluation of national science park systems: a theoretical framework and its application to the Italian and Spanish systems. Technology Analysis \& Strategic Management 25:599-614. doi: 10.1080/o9 537325.2013.785508.

Albahari, A, Klofsten, M, Rubio-Romero, JC (2019) Science and Technology Parks: a study of value creation for park tenants. The Journal of Technology Transfer, 44:1256-1272. doi: 10.1007/s10961-018-9661-9.

Albahari, A, Pérez-Canto, S, Barge-Gil, A, Modrego, A (2017) Technology Parks versus Science Parks: Does the university make the difference? Technological Forecasting and Social Change 116:13-28. doi: 10.1016/j.techfore.2016.11.012.

Ashton, C, Morton, L (2005) Managing talent for competitive advantage: Taking a systemic approach to talent management. Strategic HR Review 4:28-31. doi: $10.1108 / 147543905^{80000819 .}$ 
Autio, E, Klofsten, M (1998) A comparative study of two European business incubators. Journal of small business management 36:30-43. doi: 10.1023/a:100794180 1303.

Barney, J (1991) Firm Resources and Sustained Competitive Advantage. Journal of Management 17:99-120. doi: 10.1177/014920639101700108.

Bellavista, J, Sanz, L (2009) Science and technology parks: habitats of innovation: introduction to special section. Science and Public Policy 36:499-510. doi: 10.3152/030234209X465543.

Bergek, A, Norrman, C (2015) Integrating the supply and demand sides of public support to new technology-based firms. Science and Public Policy 42:514-529. doi: 10.1093/scipol/scuo72.

Bienkowska, D, Klofsten, M (2012) Creating entrepreneurial networks: Academic entrepreneurship, mobility and collaboration during $\mathrm{PhD}$ education. Higher Education 64:207-222. doi: 10.1007/s10734-011-9488-x.

Bøllingtoft, A, Ulhøi, JP (2005) The networked business incubator - Leveraging entrepreneurial agency? Journal of Business Venturing 20:265-290. doi: 10.1016/j. jbusvent.2003.12.005.

Cadorin, E, Johansson, SG, Klofsten, M (2017) Future developments for science parks: Attracting and developing talent. Industry and Higher Education 31:156-167. doi: 10.1177/0950422217700995.

Cannon, T (2008) The talent economy, cities and science parks. Paradigmes.

Cappelli, P (2008) Talent management for the twenty-first century. Harvard business review 86:74-82. doi: 10.1007/s10551-010-0541-y.

Chadee, D, Raman, R (2012) External knowledge and performance of offshore IT service providers in India: The mediating role of talent management. Asia Pacific Journal of Human Resources 50:459-482. doi: 10.1111/j.1744-7941.2012.00039.x.

Chartered Institute of Personnel and Development (2007).

Chartered Institute of Personnel and Development (2017) Resourcing and Talent Planning 2017.

Chordà, IM (1996) Towards the maturity stage: An insight into the performance of French technopoles. Technovation 16:143-152. doi: 10.1016/0166-4972(95) 00042-9.

Colombo, MG, Delmastro, M (2002) How effective are technology incubators? Evidence from Italy. Research Policy 31:1103-1122. doi: 10.1016/Soo48-7333(01) o0178-0.

Davidsson, P, Honig, B (2003) The role of social and human capital among nascent entrepreneurs. Journal of Business Venturing 18:301-331.

De Cleyn, SH, Braet, J, Klofsten, M (2015) How human capital interacts with the early development of academic spin-offs. International Entrepreneurship and Management Journal 11:599-621. doi: 10.1007/s11365-013-0294-z. 
De Miranda, PC, Aranha, JAS, Zardo, J (2009) Creativity: people, environment and culture, the key elements in its understanding and interpretation. Science \& Public Policy (SPP) 36:523-535.

Deeds, DL, Decarolis, D, Coombs, J (2000) Dynamic Capabilities and New Product Development in High Technology Ventures : an Empirical Analysis of New Biotechnology Firms. Journal of Business Venturing 15:211-229. doi: 10.1016/So883-9026(98) 00013-5.

Eisenhardt, KM, Graebner, ME (2007) Theory Building from Cases: Opportunities and Challenges. The Academy of Management Journal 50:25-32. doi: Article.

Ellström, P-E, Löfberg, A, Svensson, L (2011) Pedagogik i arbetslivet: Ett historiskt perspektiv. Pedagogisk forskning i Sverige.

Engel, JS, Berbegal-Mirabent, J, Piqué, JM (2018) The renaissance of the city as a cluster of innovation. Cogent Business and Management 5:1-20. doi: 10.1080/23311975 .2018 .1532777 .

Etzkowitz, H (2008) The triple helix: university-industry-government innovation in action. Routledge.

Etzkowitz, H, Zhou, C (2018) Innovation incommensurability and the science park. R\&D Management 0o, 48 :73-87. doi: 10.1111/radm.12266.

Felsenstein, D (1994) University-Related Science Parks - "seedbeds" or "enclaves" of innovation. Technovation 14:93-110. doi: 10.1016/0166-4972(94)90099-X.

Ferguson, R, Olofsson, C (2004) Science parks and the development of NTBFs location, survival and growth. The journal of technology transfer 29:5-17. doi: 10.1023/B:JOTT.ooooo11178.44095.cd.

Florida, R (2012) The Rise of the Creative Class Revisited. New York.

Florida, R (1999) The Role of the University: Leveraging Talent, Not Technology. Issues in science and technology 15:67-73. doi: 10.1086/250095.

Florin, J, Karri, R, Rossiter, N (2007) Fostering Entrepreneurial Drive in Business Education: An Attitudinal Approach. Journal of Management Education 31:17-42. doi: $10.1177 / 1052562905282023$.

Frederiksen, L, Wennberg, K, Balachandran, C (2016) Mobility and Entrepreneurship: Evaluating the Scope of Knowledge-Based Theories of Entrepreneurship. Entrepreneurship Theory and Practice 40:359-380. doi: 10.1111/etap.12223.

Fukugawa, N (2006) Science parks in Japan and their value-added contributions to new technology-based firms. International Journal of Industrial Organization 24:381-400. doi: 10.1016/j.ijindorg.2005.07.005.

Gallardo-Gallardo, E, Dries, N, González-Cruz, TF (2013) What is the meaning of "talent" in the world of work? Human Resource Management Review 23:290-300. doi: 10.1016/j.hrmr.2013.05.002.

Gibb, A, Hannon, P (2006) Towards the Entrepreneurial University. International Journal of Entrepreneurship Education 4:73-110. 
Gioia, DA, Corley, KG, Hamilton, AL (2013) Seeking Qualitative Rigor in Inductive Research: Notes on the Gioia Methodology. Organizational Research Methods 16:15-31. doi: 10.1177/1094428112452151.

Holland, P, Sheehan, C, De Cieri, H (2007) Attracting and retaining talent: exploring human resources development trends in Australia. Human Resource Development International 10:247-262. doi: 10.1080/13678860701515158.

Hommen, L, Doloreux, D, Larsson, E (2006) Emergence and growth of Mjärdevi Science Park in Linköping, Sweden. European Planning Studies 14:1331-1361. doi: $10.1080 / 09654310600852555$.

$\mathrm{Hu}$, TS (2008) Interaction among high-tech talent and its impact on innovation performance: A comparison of Taiwanese science parks at different stages of development. European Planning Studies 16:163-187. doi: 10.1080/o9654310701814462.

Huang, K-F, Yu, C-MJ, Seetoo, D-H (2012) Firm innovation in policy-driven parks and spontaneous clusters: the smaller firm the better? The Journal of Technology Transfer 37:715-731. doi: 10.1007/s10961-012-9248-9.

International Association of Science Parks and Areas of Innovation (2017) Definitions - IASP Science Park. In: http://www.iasp.ws/Our-industry/Definitions. http://www .iasp.ws/Our-industry/Definitions.

Klofsten, M, Jonsson, M, Simón, J (1999) Supporting the pre-commercialization stages of technology-based firms: The effects of small-scale venture capital. Venture Capital 1:83-93. doi: 10.1080/1369106992960o9.

Koh, FCC, Koh, WTH, Tschang, FT (2005) An analytical framework for science parks and technology districts with an application to Singapore. Journal of Business Venturing 20:217-239. doi: 10.1016/j.jbusvent.2003.12.002.

Kruse, A (2015) Innovation at a Science Park - A case study of Lindholmen Science Park. University of Gothenburg.

Laur, I (2015) Cluster Initiatives within the European Context: Stimulating Policies for Regional Development Dreams. In: New Technology Based Firms in the New Millennium. Emerald Group Publishing Limited, pp. 147-170.

Leon, N (2008) Attract and connect: The 22@Barcelona innovation district and the internationalisation of Barcelona business. Innovation 10:235-246. doi: 10.5172/ impp.453.10.2-3.235.

Löfsten, H, Lindelöf, P (2002) Science Parks and the growth of new technology-based firms - academic-industry links, innovation and markets. Research Policy 31:859876. doi: 10.1016/Soo48-7333(01)oo153-6.

Löfsten, H, Lindelöf, P (2003) Determinants for an entrepreneurial milieu: Science Parks and business policy in growing firms. Technovation 23:51-64. doi: 10.1016/ So166-4972(01)ooo86-4.

Mcdonnell, A, Collings, DG, Mellahi, K, Schuler, R (2017) Talent management: a systematic review and future prospects. European J International Management 11:86-128. 
Mjärdevi, SP (2016) Tech Pilots Report.

Nijs, S, Gallardo-Gallardo, E, Dries, N, Sels, L (2014) A multidisciplinary review into the definition, operationalization, and measurement of talent. Journal of World Business 49:180-191. doi: 10.1016/j.jwb.2013.11.002.

Papademetriou, DG, Somerville, W, Tanaka, H (2008) Talent in the 21 st -Century Economy. 40

Park, SC (2002) Science parks in Sweden as regional development strategies: a case study on Ideon Science Park. AI \& society 16:288-298. doi: 10.1007/so01460200023.

Phan, PH, Siegel, DS, Wright, M (2005) Science parks and incubators: observations, synthesis and future research. Journal of Business Venturing 20:165-182. doi: 10.1016/j.jbusvent.2003.12.001.

Saddozai, SK, Hui, P, Akram, U, et al (2017) Investigation of talent, talent management, its policies and its impact on working environment. Chinese Management Studies 11:538-554. doi: 10.1108/CMS-10-2016-0206.

Salvat, R, Marcet, X (2008) Talent management policies. Paradigmes 25-33.

Schweer, M, Assimakopoulos, D, Cross, R, Thomas, RJ (2012) Building a Well-Networked Organization. MIT Sloan Management Review 53:35.

Siegel, DS, Westhead, P, Wright, M (2003) Assessing the impact of university science parks on research productivity: Exploratory firm-level evidence from the United Kingdom. International Journal of Industrial Organization 21:1357-1369. doi:10.1016/ So167-7187(03)0oo86-9.

Siegel, R, Siegel, E, Macmillan, IC (1993) Characteristics distinguishing highgrowth ventures. Journal of Business Venturing 8:169-180. doi: 10.1016/08839026(93)90018-Z.

Silzer, R, Dowell, BE (2010) Strategic talent management matters. In: Strategy-driven talent management: A leadership imperative. pp. 3-72.

Squicciarini, M (2008) Science Parks' tenants versus out-of-Park firms: Who innovates more? A duration model. Journal of Technology Transfer 33:45-71. doi: 10.1007/ s10961-007-9037-Z.

Squicciarini, M (2009) Science parks: Seedbeds of innovation? A duration analysis of firms' patenting activity. Small Business Economics 32:169-19o. doi: 10.1007/ s11187-007-9075-9.

Storey, DJ, Tether, BS (1998) Public policy measures to support new technology-based firms in the European Union. Research Policy 26:1037-1057. doi: 10.1016/ Soo48-7333(97)00058-9.

Storey, DJ, Westhead, P (1994) An Assessment of Firms Located On and Off Science Parks in the United Kingdom. University of Illinois at Urbana-Champaign's Academy for Entrepreneurial Leadership Historical Research Reference in Entrepreneurship.

Tansley, C (2011) What do we mean by the term "talent" in talent management? Industrial and Commercial Training 43:266-274. doi: 10.1108/00197851111145853. 
Thunnissen, M, Boselie, P, Fruytier, B (2013) A review of talent management: "infancy or adolescence?" International Journal of Human Resource Management 24:17441761. doi: 10.1080/09585192.2013.777543.

Vásquez-Urriago, ÁR, Barge-Gil, A, Rico, AM, Paraskevopoulou, E (2014) The impact of science and technology parks on firms' product innovation: empirical evidence from Spain. Journal of Evolutionary Economics 24:835-873. doi: 10.1007/ so0191-013-0337-1.

Vedovello, C (1997) Science parks and university-industry interaction: Geographical proximity between the agents as a driving force. Technovation 17:491-531. doi: 10.1016/So166-4972(97)00027-8.

Westhead, P, Batstone, S (1998) Independent Technology-based Firms: The Perceived Benefits of a Science Park Location. Urban Studies 35:2197-2219. doi: 10.1080/ 0042098983845 .

Westhead, P, Storey, DJ (1995) Links between higher education institutions and high technology firms. Omega 23:345-36o. doi: 10.1016/0305-0483(95)00021-F.

Yang, CH, Motohashi, K, Chen, JR (2009) Are new technology-based firms located on science parks really more innovative?: Evidence from Taiwan. Research Policy 38:77-85. doi: 10.1016/j.respol.2008.09.001.

Yin, RK (2003) Case Study Research: Design and Methods, 3rd edn. Sage Publications. Applied Social Research Methods Series; Volume 5. 
Appendix - Overview of the respondents

SPM Founding director This respondent provided us with data and and former CEO insights of SPM Office, Soft-landing and Shadow of SPM Board. We had five personal meetings, and a number of emails exchanged over 2016. The meetings were held at Linköping University.

Current park This respondent validated the first four SPM cases CEO and provided us with information about Tech Pilots project. We had three personal meetings, one at the IASP international conference in 2016.

CEO of LEAD and Our first contact with LEAD in this project was deputy CEO of during a presentation in which the CEO exposed LEAD the incubator's activities to attract qualified professionals for their start-ups. We arranged a lunch meeting to explain our research in more detail and took the opportunity to get the first insights into the talent attraction processes performed by LEAD. In addition, we had a telephone meeting in order to get more information about LEAD stakeholders, results and future challenges. A second phone meeting was held to get more detailed information on how LEAD use its networks, like regional partners, when attracting talent to its start-ups. Other questions and the validation of the case were made through exchanging emails.

LSP Current park CEO

During the first Skype meeting with this respondent several talent activities were identified, but the Geely case (CEVT) seemed to be the most interesting at that time, for many reasons, such as the involvement of two quite different cultures (China and Sweden) and the relevance of the companies involved (Geely and Volvo). After this meeting, we exchange a few emails aiming to compose the case, and we had a last Skype meeting to confirm the data we have put in the table 1. 
ISP Current park CEO In the first Skype meeting, we introduce ourselves, our study and the purpose of our contact, that is, we are interested in discovering a new talent case in the ISP. In common agreement, we chose Ideon Meeting because its potential in creating networking opportunities and new business possibilities as well as sharing knowledge and experience, thus providing a favourable environment for attracting new talent to the companies in the park.

Operations This manager was indicated by the CEO of ISP and Manager of Ideon was responsible for providing us with detailed Meeting. information about Ideon Meeting, as well as for the validation of the data we put in the table 1 regarding Ideon Meeting, pointing out any incorrect or inaccurate facts. Firstly, we had a phone meeting to briefly explain our study and how we plan to make a short case about Ideon Meeting. After a few emails exchanged, we had a Skype meeting to check the table and conclude the case. 